Vol 5 No 2 (2022) 254-262 P-ISSN 2620-295 E-ISSN 2747-0490 DOI: 1047467/elmal.v5i2.768

\title{
Analisa Peningkatan Minat terhadap Produk Asuransi Syariah
}

\author{
Soibatul Aslamia Nasution ${ }^{1}$, Nuri Aslami ${ }^{2}$ \\ ${ }^{1,2}$ Program Studi Ekonomi dan Bisnis Islam, Universitas Islam Negeri Sumatera Utara \\ soibatulasImianasution@gmail.com
}

\begin{abstract}
The purpose of this research is to find out why the public interest in sharia insurance products is not too high, which is based on various factors of consideration both from the community and from the management of Islamic insurance companies. This study uses a qualitative approach, using data processing techniques based on interviews, observations, and documentation related to this research. The research results obtained are factors that are of interest to the community towards sharia insurance products, which must maintain a good reputation reflecting the quality and quantity of sharia insurance products and this is an assessment of the community itself. So that the better reputation of Islamic insurance will be an attraction for the public interest in Islamic insurance products.
\end{abstract}

\section{Keywords: islamic insurance, interest, influence}

\section{ABSTRAK}

Tujuan dari penelitian ini adalah untuk mengetahui mengapa animo masyarakat terhadap produk asuransi syariah tidak terlalu tinggi, yang didasarkan pada berbagai faktor pertimbangan baik dari masyarakat maupun dari pihak manajemen perusahaan asuransi syariah. Penelitian ini menggunakan pendekatan kualitatif, dengan menggunakan teknik pengolahan data berdasarkan wawancara, observasi, dan dokumentasi yang berkaitan dengan penelitian ini. Hasil penelitian yang diperoleh adalah faktor-faktor yang diminati masyarakat terhadap produk asuransi syariah, yaitu harus menjaga reputasi yang baik yang mencerminkan kualitas dan kuantitas produk asuransi syariah dan ini merupakan penilaian dari masyarakat itu sendiri. Sehingga semakin baik reputasi asuransi syariah akan menjadi daya tarik bagi minat masyarakat terhadap produk asuransi syariah.

Kata kunci: asuransi syariah, bunga, pengaruh

\section{PENDAHULUAN}

Asuransi syariah merupakan usaha yang aktivitasnya saling melindungi serta tolong menolong diantara sejumlah orang atau pihak melalui investasi dalam bentuk aset yang menyampaikan pola pengembalian untuk menghadapi risiko eksklusif melalui perikatan sesuai prinsip syariah. pada Indonesia lembaga syariah kini berkembang 
Vol 5 No 2 (2022) 254-262 P-ISSN 2620-295 E-ISSN 2747-0490 DOI: 1047467/elmal.v5i2.768

menggunakan sangat pesat baik itu iuran pertanggungan ataupun perbankan serta usaha lainnya yang sesuai prinsip-prinsip syariah (Sula, 2004). Filosofi pada iuran pertanggungan syariah yaitu lembaga yang tak bisa terlepas dari semangat sosial serta saling tolong menolong (Ali, 2014).

Pentingnya iuran pertanggungan syariah bagi kehidupan insan yaitu sifatnya untuk memberikan perlindungan secara jangka panjang. tidak satupun manusia yang menginginkan atau merencanakan sebuah hal atau insiden yang tidak diinginkan contohnya, sakit, kecelakaan, bahkan kematian. namun tidak satupun juga insan bisa mengetahuinya dari awal sebab hal tersebut ialah insiden dan yang sudah dikuasakan ilahi sang pencipta. namun manusia dapat menyampaikan perencanaan untuk mengatasi hal atau insiden yang tidak diinginkan tadi karena peristiwa buruk tersebut tak bisa dihindari tapi hanya dapat diantisipasi, hal ini adalah fungsi berasal perusahaan iuran pertanggungan syariah yaitu bersifat saling tolong menolong serta melindungi. perjuangan serta upaya menghindari resikonya dilakukan menggunakan cara melimpahkannya pada pihak lain, maka pilihan yang paling sempurna yaitu di institusi yang bernama iuran pertanggungan (Syahatah, 2006).

Apabila ditelaah bahwa eksistensi perusahaan iuran pertanggungan syariah pada Indonesia sudah ada selama lebih kurang 24 tahun hingga kini dan terus mengalami pertumbuhan berasal tahun ketahun. Walaupun telah mengalami banyak perkembangan, namun masih banyak masyarakat yang kurang berminat atau masih enggan buat memakai jasa iuran pertanggungan syariah sebab banyak sekali alasan pertimbangan, tentunya ini sebagai tantangan tersendiri bagi perusahaan iuran pertanggungan syariah buat bisa memaksimalkan perluasan produknya agar bisa diminati sang masyarakat luas.

Alasan tersebut dikarenakan oleh beberapa faktor antara lain yaitu: (a) masyarakat muslimdi Indonesia umumnya kurang tahu apa tujuan dari premi; (b) lalu rakyat muslim masih anti dengan produk asuransi; (c) terdapat opini bahwa iuran pertanggungan itu seperti mendahului kehendak ilahi; (d) Kurangnya sosialisai kepada warga mengenai adanya forum iuran pertanggungan syariah pula berdampak di minat rakyat buat memakai produk iuran pertanggungan syariah. Akibatnya, info yang berkaitan menggunakan iuran pertanggungan syariah tidak tersampaikan kepada masyarakat; (e) Faktor ekonomi rakyat seperti pada pedesaan cenderung menengah kebawah, sedangkan pada jasa asuransi, setiap orang yang mengikuti asuransi diwajibkan membayar iuran pertanggungan sesuai dengan konvensi yang didesain; (f) tingkat kesadaran masyarakat Indonesia masih sangat rendah mengenai risiko yang akan 


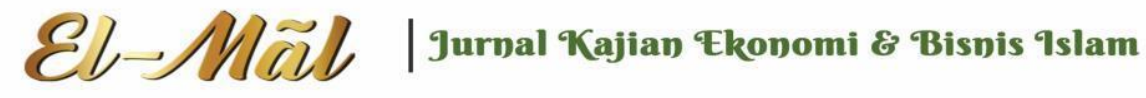

\section{Vol 5 No 2 (2022) 254-262 P-ISSN 2620-295 E-ISSN 2747-0490 DOI: $1047467 /$ elmal.v5i2.768}

datang dikemudian hari. Hal ini dikarenakan asuransi disebut bukan menjadi kebutuhan yang utama akan tetapi menjadi kebutuhan pelengkap.

Minat adalah kecenderungan buat menyampaikan perhatian dan bertindak terhadap orang, aktivitas atau situasi yang menjadi objek asal minat tersebut dengan disertai perasaan suka. Selain itu minat ialah sumber motivasi yang mendorong orang buat melakukan apa yang mereka inginkan jika mereka bisa bebas memilih, Jika mereka melihat bahwa sesuatu yang akan menguntungkan mereka merasa berminat. adalah bila minat masyarakat semakin tinggi maka produk asuransi syariah dapat dinikmati rakyat secara luas, bahkan menjadi kebutuhan primer. tidak hanya bagi rakyat yang berpenghasilan menengah ke atas tetapi bagi warga menengah ke bawah juga sebab setiap orang dibutuhkan premi untuk memberikan keamanan serta tingkat risiko yang lebih rendah sebab setiap risiko tidak bisa dihilangkan atau dihindari namun dilindungi pada masa yang tidak dapat diidentifikasi menggunakan pasti.

\section{METODE PENELITIAN}

Penelitian ini merupakan penelitian dengan pendekatan kualitatif dengan menggunakan data verbal bukan angka. Teknik penelitian ini yaitu menggunakan tahaptahap yaitu wawancara, observasi, dokumentasi. Teknik analisis data dalam penulisan ini dilakukan secara deskriptif analisis, yaitu prosedur pemecahan masalah yang diteliti dengan cara memaparkan data yang diperoleh dari hasil pengamatan lapangan, kemudian dianalisis dan di interprestasikan dengan memberikan kesimpulan. Dalam hal pemeriksaan keabsahan temuan yaitu diperlukan teknik pemeriksaan. Pelaksanaan teknik pemeriksaan didasarkan atas sejumlah kriteria tertentu. Ada empat kriteria yang digunakan yaitu, derajat kepercayaan (credebility), keteralihan (transferability), kebergantungan (dependability), dan kepastian (confirmability). Penelitian ini menggunakan dua kriteria yaitu derajat kepercayaan dan kepastian

Uji keabsahan data menggunakan kriteria derajat kepercayaan (credebility) penelitian ini menggunakan dua teknik pemeriksaan data yaitu ketekunan pengamatan dan triangulasi. Ketekunan pengamatan berarti mencari secara konsisten interpretasi dengan berbagai cara dalam kaitan dengan proses analisis yang konstan atau tentatif. Ketekunan pengamatan bermaksud menemukan ciri-ciri dan unsur-unsur dalam situasi yang sangat relevan dengan persoalan atau isu yang sedang dicari dan kemudian memusatkan diri pada hal-hal tersebut secara rinci. Hal itu berarti peneliti hendaknya mengadakan pengamatan dengan teliti dan rinci secara berkesinambungan terhadap faktor-faktor yang menonjol. Triangulasi diartikan sebagai teknik pengumpulan data yang bersifat menggabungkan dari berbagai teknik pengumpulan data dan sumber data 
Vol 5 No 2 (2022) 254-262 P-ISSN 2620-295 E-ISSN 2747-0490 DOI: 1047467/elmal.v5i2.768

yang telah ada. Pada penelitian ini yang digunakan yaitu triangulasi metode pengumpulan data dan triangulasi sumber data.

Triangulasi Metode Pengumpulan Data yaitu sebagai berikut:

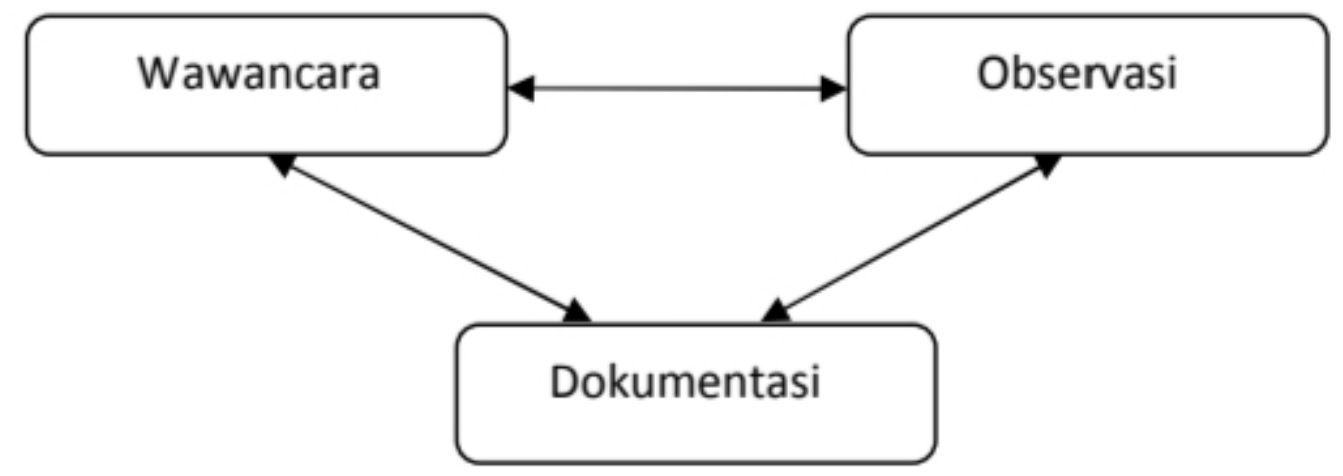

Triangulasi sumber data merupakan membandingkan dan mengecek balik derajat kepercayaan suatu informasi yang diperoleh melalui waktu dan alat yang berbeda dalam penelitian kualitatif.

\section{HASIL PENELITIAN DAN PEMBAHASAN}

Berikut adalah hasil wawancara dari penelitian dengan pihak perusahaan asuransi dan masyarakat:

1. Apakah produk yang ada di Asuransi Syariah dapat mudah di pahami masyarakat awam?

Jawaban: Asuransi Syariah memiliki kemampuan yang baik dalam menyampaikan produknya dalam masyarakat.

2. Apakah produk yang ada di Asuransi Syariah telah dijalankan sesuai dengan hukum syariah?

Jawaban: Produk asuransi syariah telah dirancang untuk memenuhi kebutuhan masyarakat akan rancangan keuangan yang sesuai dengan syariat Islam, sesuai dengan surat keputusan kementerian keuangan Indonesia No. 241KMK.017/1995 Tanggal 1 Juni 1995. Yang memiliki 2 akad yaitu akad tabarru' dan tijarah yaitu tolong menolong dan non profit oriented.

3. Apakah produk yang tersedia di Asuransi Syariah telah terbukti menjadi penolong bagi masyarakat? 
Vol 5 No 2 (2022) 254-262 P-ISSN 2620-295 E-ISSN 2747-0490 DOI: 1047467/elmal.v5i2.768

Jawaban: Asuransi Syariah memberikan santunan meninggal dunia atau cacat total sementara dan tetap, dan, jika nasabah meninggal dunia sebelum berusia 99 tahun maka akan mendapatkan manfaat santunan asuransi dan manfaat nilai tunai serta jika peserta yang diasuransikan hidup sampai dengan tanggal akhir pertanggungan maka akan mendapatkan manfaat nilai tunai.

4. Apakah agency yang melakukan promosi produk asuransi syariah sudah menyampaikan penjelasan produk tersebut dengan rinci?

Jawaban: Agency Asuransi Syariah adalah agency yang memiliki ilmu pengetahuan asuransi secara baik. Agency yang melakukan promosi dan memberikan penjelasan kepada masyarakat telah melakukan hal tersebut sesuai dengan prosedur.

5. Apakah penyebaran promosi sudah mumpuni untuk diketahui oleh keseluruhan masyarakat?

Jawaban: Sangat mumpuni, dikarenakan promosi yang dilakukan perusahaan asuransi syariah tidak hanya melalui agency tetapi juga seminar, website, brosur dan lainnya.

6. Apakah kegiatan promosi dilakukan bersamaan dengan kegiatan seminar mengenai asuransi syariah?

Jawaban: Ya, benar. Seminar umum kepada masyarakat di daerah yang masyarakatnya kurang memahami asuransi seperti di kawasan pesisir atau pendesaan.

7. Apakah masyarakat yang berpendapatan dibawah rata-rata bisa berkesempatan untuk menjadi nasabah asuransi syariah?

Jawaban: Bisa, dikarekan dalam asuransi syariah calon nasabah diberikan pilihan pembayaran premi sesuai dengan kesanggupan meraka masing-masing.

8. Apakah pendapatan berpengaruh pada masyarakat dalam pembayaran jumlah premi?

Jawaban: Ya, jelas. Pembayaran premi disesuaikan dengan kesanggupan calon nasabah itu sendiri. 
Vol 5 No 2 (2022) 254-262 P-ISSN 2620-295 E-ISSN 2747-0490 DOI: 1047467/elmal.v5i2.768

9. Apakah dengan berasuransi bisa membuat masyarakat terjamin hidupnya dimasa yang akan datang?

Jawaban: Insyaallah bisa, dikarenakan fungsi asuransi itu sendiri.

10. Bagaimana minat masyarakat terhadap produk asuransi Syariah?

Jawaban: Sejauh ini minat masyarakat dalam berasuransi masih rendah dikarenakan timbulnya beberapa faktor, misalnya masyarakat yang masih takut karena pengalaman berasuransi mereka diasuransi sebelumnya. Namun sampai saat ini peningkatan jumlah nasabah kerus naik secara signifikan.

Dari hasil penelitian didapat bahwa pihak Asuransi Syariah sudah memiliki kemampuan yang baik dalam menjelaskan produknya pada masyarakat, hal ini terbukti bahwa tidak semua masyarakat belum mengetahui tentang produk Asuransi Jiwa Syariah yang merupakan kebutuhan jangka panjang. Strategi perusahaan Asuransi Syariah dalam melakukan promosi yaitu dengan melakukan: Pihak agency dalam melakukan promosi produk sudah dilakukan secara rinci kepada masyarakat dan telah melakukan hal tersebut sesuai dengan prosedur, Agency juga memiliki ilmu pengetahuan yang baik/mumpuni untuk menjelaskan produk secara detail mengenai prosedur serta persyaratan yang tertera pada produk tersebut. Kegiatan Promosi dilakukan tidak hanya melalui agency tetapi juga seminar kepada masyarakat pedesaan yang belum terlalu memahami asuransi.

Adapun Strategi promosi dilakukan melalui website yang dapat dilihat pada internet, brosur yang bisa didapat dari sebaran yang dilakukan oleh agency, dan iklan yang dapat kita lihat di televisi, gadget, spanduk serta yang lainnya. Kegiatan promosi juga dilakukan secara bersamaan disetiap adanya kegiatan seminar umum mengenai asuransi. Pihak Asuransi prudential menempatkan sasaran untuk melakukan seminar umum pada masyarakat pesisir yang pengetahuannya rendah mengenai Asuransi Syariah yang tujuannya untuk kebutuhan jangka panjang masyarakat. Masyarakat masih beranggapan bahwa pendapatan berpengaruh jika masyarakat bergabung untuk menjadi nasabah. Pada kenyataannya sistem Asuransi syariah berprinsip saling tolong-menolong, dari prinsip tersebut dapat dikatakan bahwa asuransi syariah adalah tabungan jangka panjang untuk dimasa yang akan datang. Dengan mengikuti asuransi, masyarakat akan terjamin dimasa yang akan datang sesuai dengan fungsi yang diberikan oleh asuransi itu sendiri. 


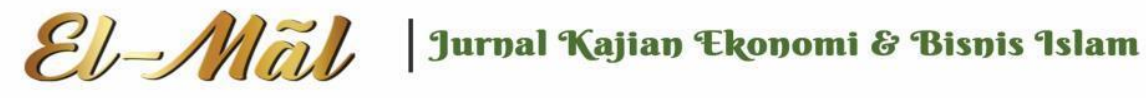

\section{Vol 5 No 2 (2022) 254-262 P-ISSN 2620-295 E-ISSN 2747-0490 DOI: $1047467 /$ elmal.v5i2.768}

Faktor-faktor yang mempengaruhi minat masyarakat dalam berasuransi syariah sangat penting diperhatikan demi kelangsungan dan tetap eksisnya lembaga tersebut. Berdasarkan wawancara yang dilakukan oleh peneliti terhadap informan mengenai faktor-faktor yang mempengaruhi minat masyarakat terhadap produk asuransi syariah bahwa perusahaan asuransi memiliki peran penting bagi masyarakat, dikarenakan sistem asuransi syariah yang berprinsip saling melindungi dan tolong-menolong diantara sejumlah orang /pihak melalui investasi dalam bentuk asset atau tabarru' yang memberikan pola pengembalian untuk menghadapi risiko tertentu melalui akad (perikatan) yang sesuai syariah.

\section{KESIMPULAN DAN SARAN}

Berdasarkan hasil penelitian ini maka dapat disimpulkan bahwa:

1. Untuk meningkatkan minat masyarakat pada produk asuransi syariah, ada bebarapa faktor yang mempengaruhi minat masyarakat terhadap produk asuransi syariah yaitu pertama produk yang dipasarkan kepada konsumen atau masyarakat. Kedua promosi yang dilakukan oleh agency kepada masyarakat yang sudah mengenal dan menggunakan jasa asuransi maupun yang belum memahami apa itu asuransi, ketiga pendapatan masyarakat tidak memiliki pengaruh ketika masyarakat itu menjadi nasabah dikarenakan jumlah pembayaran premi dapat disesuaikan dengan jumlah pendapatan calon nasabah/nasabah.

2. Terkait dengan strategi promosi produk, kegiatan Promosi dilakukan tidak hanya melalui agency tetapi juga seminar kepada masyarakat pedesaan yang belum terlalu memahami asuransi. Adapun Strategi promosi yang dilakukan melalui website yang dapat dilihat pada internet, brosur yang bisa didapat dari sebaran yang dilakukan oleh agency, dan iklan yang dapat kita lihat di televisi, gadget,spanduk serta yang lainnya. Kegiatan promosi juga dilakukan secara bersamaan disetiap adanya kegiatan seminar umum mengenai asuransi.

Berdasarkan kesimpulan tersebut, maka dapat direkomendasikan sebagai berikut:

1. Manajemen dari perusahaan asuransi syariah yaitu agar melakukan kegiatankegiatan yang dapat menarik minat masyarakat mengenai produk asuransi jiwa syariah. Salah satu cara yang dapat dilakukan oleh pihak asuransi syariah adalah dengan melakukan kegiatan bazzar disetiap akhir pekan, dimana dalam bazzar tersebut penjelasan diberikan kepada setiap masyarakat yang hadir didalam kegiatan bazzar tersebut. 
Vol 5 No 2 (2022) 254-262 P-ISSN 2620-295 E-ISSN 2747-0490 DOI: 1047467/elmal.v5i2.768

2. Manajemen perusahaan asuransi syariah agar meningkatkan kegiatan promosi dan seminar kepada masyarakat yang membutuhkan informasi mengenai asuransi jiwa syariah, agar masyarakat yang ingin menjadi nasabah asuransi syariah dapat memahami prinsip asuransi jiwa syariah. Hal ini dikarenakan masyarakat sudah terlanjur kecewa oleh pihak asuransi yang mereka gunakan sebelumnya.

\section{DAFTAR PUSTAKA}

Ali, A. Hasyim. (1993). Bidang Usaha Asuransi, cet 1, Jakarta: Bumi Askara.

Ali, Hasan AM. (2014). Asuransi Dalam Perspektif Hukum Islam. Jakarta: Kencana.

Dewi, Gemala. (2004). Aspek-Aspek Hukum dalam Perbankan dan Perasuransian Syariah di Indonesia. Jakarta: Prenada Media.

DSN-MUI dan Bank Indonesia. Himpunan Fatwa Dewan Syariah Nasional MUI, Edisi Revisi 2006. Jakarta: DSN-MUI. 2006.

Hermansyah. (2006). Hukum Perbankan Nasional Indonesia. Jakarta: Kencana.

Jazwari, Yadi dan H. A. Dzajuli. (2002). Lembaga-lembaga Perekonomian Umat (Sebuah Pengenalan). Jakarta: PT Raja Grafindo Persada.

Kurniawan, Ar-Riba Wa At-Ta'min, Bandung: Pustaka Hidayah.

Muhaimin, Iqbal. (2005). Asuransi Umum Syariah dalam Praktik. Jakarta: Gema Insani Press.

Murtika, I ketut dan Prakoso, Djoko. (2000). Hukum Asuransi Indonesia. Jakarta: PT Rineka Cipta.

Muthahhari, Murtadha. (1995). Pandangan Islam Tentang Asuransi dan Riba, Terjemah:Irwan

Salim, Abbas. (1995). Dasar-dasar Asuransi. Jakarta: PT Raja Grafindo Persada.

Suhendi, Hendi dan Yusuf, Deni K. (2005). Asuransi Takaful dari Teoritis Ke Praktik. Bandung: Mimbar Pustaka.

Sula, Muhammad Syakir. (2004). Asuransi Syariah Konsep Dan Sistem Operasional. Jakarta: GIP.

Syahatah, Husain. (2006). Asuransi Dalam Perspektif Syariah. Jakarta: Sinar Grafika Offset.

Tjiptono, Fandy, (2014). Strategi Pemasaran. Yogyakarta: Andi Press. 
Cl, Pl/TLl Iurnal Kajian Ekonomi \& Bisnis Islam

Vol 5 No 2 (2022) 254-262 P-ISSN 2620-295 E-ISSN 2747-0490 DOI: 1047467/elmal.v5i2.768

Undang-Undang No 40 Tahun 2014 Tentang Perasuransian. 